\title{
Tectonostratigraphic terranes and zones juxtaposed along the Mid-Hungarian Line: their contrasting evolution and relationships
}

\author{
Sándor Kovács† \\ Geological, Geophysicaland Space Science Research \\ Group of the HungarianAcademy of Sciences, Budapest
}

János Haas

Geological, Geophysicaland Space Science Research

Group of the HungarianAcademy of Sciences, Budapest

\author{
György Buda* \\ Department of Mineralogy, Eötvös Loránd \\ University, Budapest
}

Károly Brezsnyánszky

Geological Institute of Hungary, Budapest

Szabolcs Harangi

Department of Petrology and Geochemistry, Eötvös

Loránd University, Budapest

The Mid-Hungarian (or Zagreb-Zemplin) Line of WSW-ENE strike divides the Pannonian basement into two mega-units, the Tisia Composite Terrane in the SE and the ALCAPA Composite Terrane in the NW. They became juxtaposed no earlier than the Middle Miocene (Karpathian). Their present adjacent zones show very different Variscan and Alpine evolution and relationships, which are briefly reviewed here and confronted in the light of detailed correlational work published during the last decade. The present contribution summarizes Variscan and Alpine evolution of units/terranes juxtaposed along the Mid-Hungarian Line, the major terrane boundary in the pre-Neogene basement of the Pannonian Basin, as can be seen on the Circum-Pannonian terrane maps.

Key words: tectonostratigraphic terranes, Mid-Hungarian Line, Mid-Hungarian Zone, Mecsek Zone, Variscan evolution, Alpine evolution, Hungary

\section{Introduction}

In the basement of the Pannonian Basin the Mid-Hungarian Line (MHL) separates two significantly different tectonostratigraphic units. Constituting the southernmost part of the ALCAPA Composite Terrane, the South-Alpine and Dinaridic-related Mid-Hungarian Zone occurs presently to its north, whereas the European-related Mecsek Zone of the Tisia Composite Terrane is now located to the south of the MHL. Accordingly, the MHL separates displaced/exotic terranes of fundamentally different evolution from the Late Paleozoic to the Tertiary;

\footnotetext{
Addresses: S. Kovács, Gy. Buda, J. Haas, Sz. Harangi: H-1117 Budapest Pázmány P. sétány 1/c, Hungary. *Corresponding author; e-mail: buda@ludens.elte.hu K. Brezsnyánszky: H-1143 Budapest, Stefánia út 14, Hungary

Received: February 22, 2011; accepted: April 26, 2011
} 
large-scale displacement led to their juxtaposition. The aim of this paper is to summarize the evidence for the different development of the presently juxtaposed terranes and to prove the applicability of the terrane concept for this region.

\section{The Mid-Hungarian Line}

The Mid-Hungarian (or Zagreb-Zemplín) Line is defined as the northwestern border of the Tisia Composite Terrane (Fülöp et al. 1987), separating it from the ALCAPA Composite Terrane. It is drawn on maps (cf. Figs 1,2) based primarily on borehole data, since on deep seismic sections it is not unambiguously apparent (Csontos and Nagymarosy 1998).

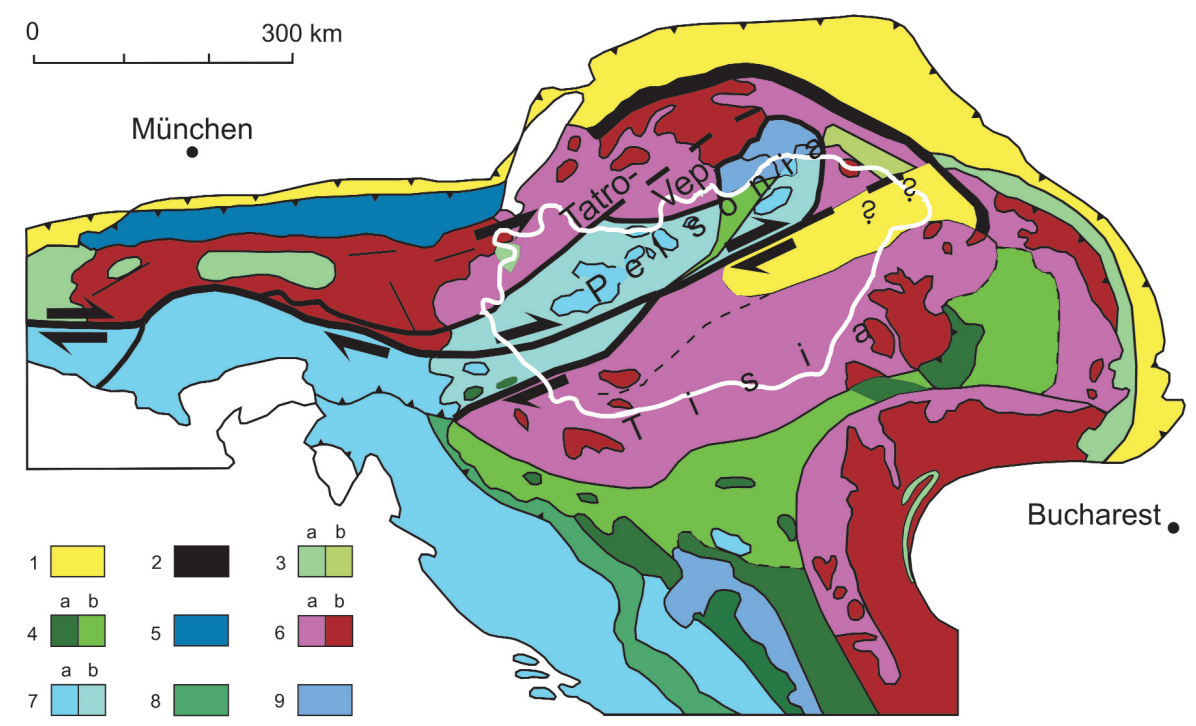

Fig. 1

Tectonic/terrane sketch of the pre-Neogene basement of the Pannonian Basin and the surrounding Alpine-Carpathian-Dinaridic ranges (after Kovács et al. 2000, Fig. 1). 1. Alpine-Carpathian and "Intrapannonian" (Szolnok-Maramures) flysch zone; 2. Pieniny Klippen Belt; 3. Ophiolite zones related to the Penninicum of the Alps-Carpathians, resp. to the Outer Dacides of the East and South Carpathians; (a: at surface, b: in the pre-Tertiary basement); 4. Vardar or Inner Dinaridic and related ophiolite zones (a: at surface, b: in the pre-Tertiary basement); 5. Units representing the northern, resp. northeastern continental margin of the Neotethyan (Vardar, resp. Inner Dinaridic) oceanic system; 6. The same as before, with polymetamorphic pre-Alpine basement (Austroalpine, TatroVeporic, Median and Marginal Dacidic to Serbo-Macedonian); 7. Units representing the "southern", resp. "southwestern" continental margin of the Neotethyan (Vardar, resp. Inner Dinaridic) oceanic system; 8. Eohellenic Bosnian Flysch Zone ("Sarajevo sigmoid" in the sense of Dimitrijevic 1992); 9. Drina-Ivanjica unit of the Inner Dinarides, Gemer and Aggtelek-Silica units of the Pelsonia Composite Terrane) 


\section{Northern zones of the Tisia Composite Terrane (TCT)}

The Variscan basement of the southwestern part of the Alpine Tisia Composite Terrane (TCT) is made up by the (Slavonia-) Dravia Unit (Variscan Terrane), extending from Croatia (Papuk and Psunj Complexes) to $\mathrm{N}$ of the Drava River. From the area of the Mecsek and Villány Mts toward ENE, the Kunság Unit (Variscan Terrane) forms the basement of the Alpine Mecsek and Villány (-Bihor) zones in the basement of the Great Plain (Szederkényi 1996; Kovács et al. 2000). The Mórágy Complex in the western parts of TCT (basement of the Mecsek Zone) is characterized by Variscan granitoids. The granitoids are approx. 340-354 Ma old according to U-Pb dating (Klötzli et al. 2004; for a review of all available former and recent geochronological data see Shatagin et al. 2005). According to

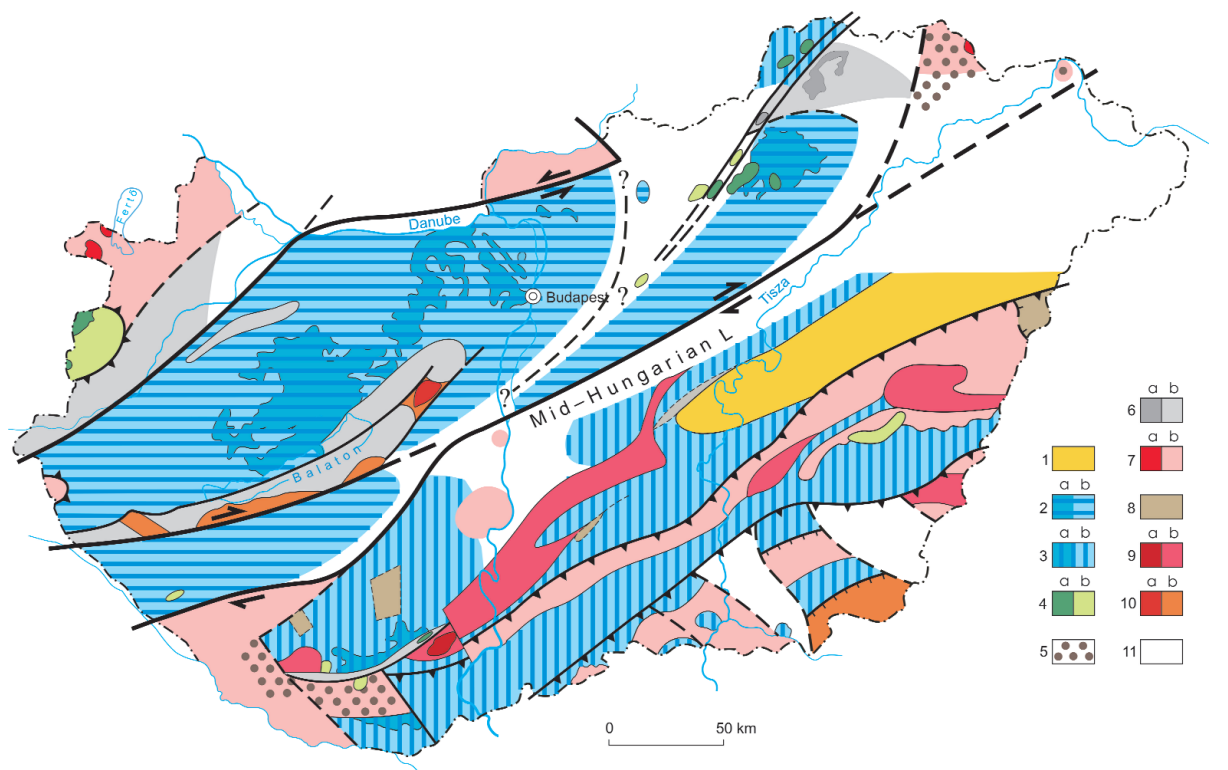

Fig. 2

Tectonostratigraphic terranes in Hungary (after Kovács et al. 2000, Fig. 3). 1. Szolnok Flysch Zone; 2. Alpine overstep sequence connected to the southern (South Alpine-Dinaridic) shelf of the Vardar and related Neotethyan oceanic basins; 3. Alpine overstep sequence connected to the northern (East Alpine-Carpathian) shelf of the Vardar and related Neotethyan oceanic basins; 4. Alpine ophiolitic assemblages (Pelsonia and Penninic Composite Terranes) and Pre-Alpine ultrabasics, eclogite and amphibolite (Tisia Terrane); 5. Post-Variscan, Late Carboniferous overstep sequence with anthracite seams (Zemplenicum Terrane and southwestern part of the Tisia Terrane); 6. Variscan "overstep"-type (shelf) sequence (with abundant Devonian carbonates, as well as with very low to low-grade Variscan metamorphism in Transdanubia and most probably without Variscan metamorphism in the Bükkium of NE Hungary) (East Alpine units and Pelsonia Composite Terrane); 7. Variscan medium-grade metamorphosed complexes; 8. Variscan low to very low-grade metamorphosed, predominantly siliciclastic complexes (Tisia Terrane); 9. "Syncollisional" (in the sense of Buda 1995 and of Klötzli et al. 1999) granitoids (migmatitic complexes); 10. Postcollisional granitoids (intrusions); 11 . No drilling data for the pre-Neogene basement. Darker shade (marked by "a" in the legend) indicates surface outcrops and lighter shade (marked by "b" in the legend) occurrences in the Pre-Neogene basement 
earlier interpretations they are (I- or S-type) "synorogenic" granitoids (Buda 1996; Klötzli et al. 1999). However, according to latest results they were formed by continent-continent collision during the post-closure uplift stage (Buda et al. 2004; Buda and Dobosi 2004). They are I-type, metaluminous, calc-alkaline, high$\mathrm{K}$ and high-Mg-bearing large intrusion(s), with small lamprophyre-derived, ultrapotassic, Mg-Ca-rich, low Al and Si intrusions and/or enclaves (durbachite). Because of the Ca activity apatite, titanite, and a large amount of allanite were crystallized in the enclaves as well as in the enclosing granitoids. Allanite is the major REE-bearing mineral which controls the whole-rock REE patterns. It is oxidized $\left(\mathrm{Fe}^{3+} / \mathrm{Fe}^{\mathrm{tot}} \approx 0.4\right)$, which is characteristic of I-type granitoids. In enclaves allanite contains more $\Sigma$ REE and is slightly depleted in Ca compared with the allanite occurring in granitoids. Basic melt originated from the upper mantle; acidic melt was formed by partial melting of the continental crust. The two melts probably crystallized at the same time (Figs 3-6). In the transecting peraluminous microgranite dikes allanite was not identified (Buda et al. 2009). It is accompanied by migmatite-gneiss and micaschist on both its flanks. The TCT belonged to the Moldanubicum Zone of the Variscan orogenic belt (Fig. 3; Buda et. al. 2010).

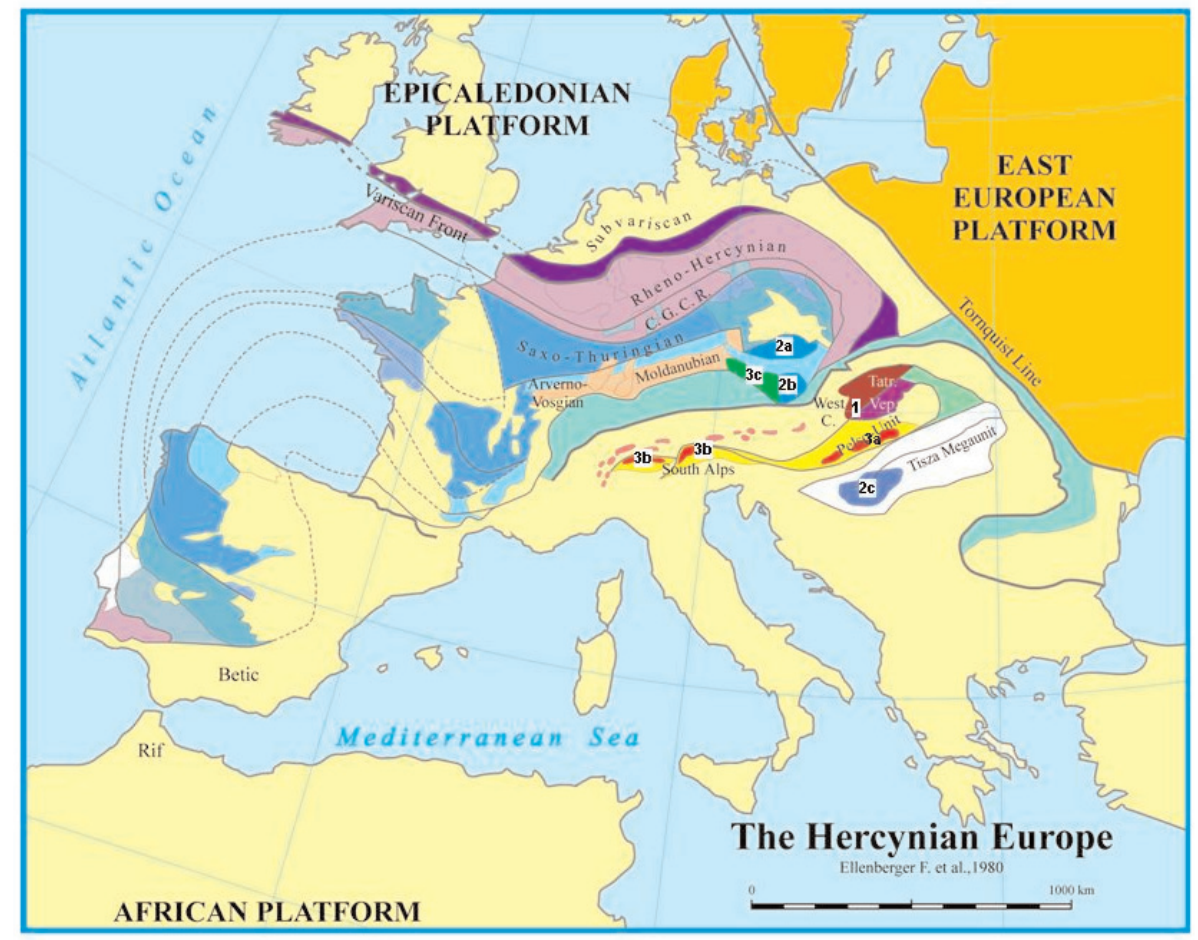

Fig. 3

Variscan Europe (after Ellenberger et al. 1980) 1. Western Carpathian, 2a. Central Bohemia, 2b. Eastern part of southern Bohemia, 2c. Tisia Composite Terrane, 3a. Pelso Terrane, 3b. Southern Alps, 3c. Western part of southern Bohemia 
Fig. 4

Discriminant analysis of granitoids from Central Europe. 1. Western Carpathian plutons, 2. Central Bohemian plutons, eastern part of southern Bohemian plutons, Tisia Terrane, 3. Pelso Terrane, Southern Alps, western part of southern Bohemia plutons (counted by J. Kovács and Gy. Buda)

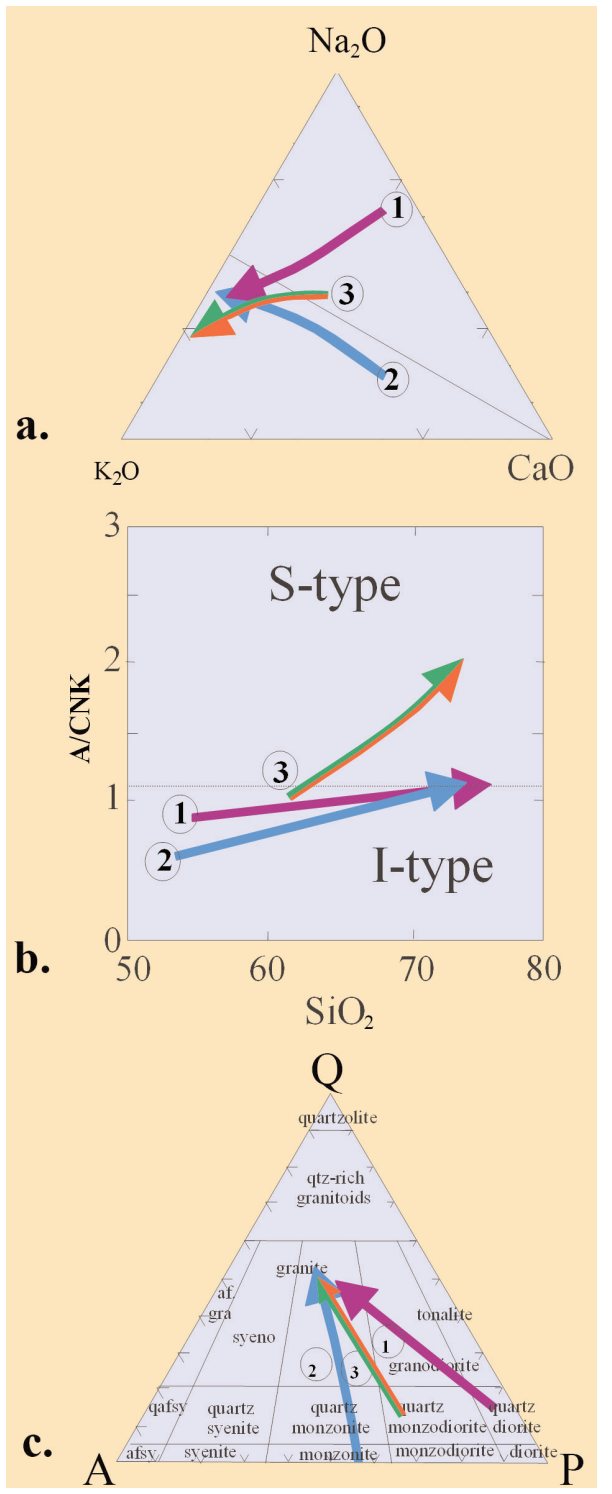

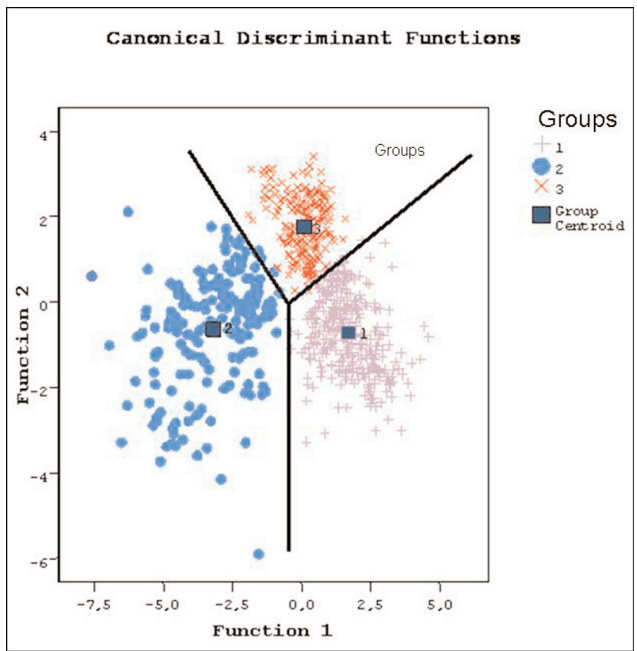

In the Körös Complex (basement of the Villány Zone) medium-grade metamorphic rocks predominate; granitoids are less common. Both in the Slavonia-) Dravia and Kunság Units two characteristic metamorphic events were recognized: an earlier, mediumpressure, Barrow-type (average age: 350-330 Ma) and a later, low pressure high temperature one (age: 330-320 Ma; Szederkényi 1996; Lelkes-Felvári et al. 1996). The former was accompanied by anatectic granitization. Relics of low to very low-grade metamorphosed units (as Variscan nappe outliers or in wrench-zones) and high-pressure metamorphics (early Variscan age) are also known.

Fig. 5

Composition of Central European granitoids. a. $\mathrm{K}_{2} \mathrm{O}-\mathrm{Na}_{2} \mathrm{O}-\mathrm{CaO}$ diagram. b. A/CNK $\left(\mathrm{Al}_{2} \mathrm{O}_{3}\right)$ $\left(\mathrm{CaO}+\mathrm{Na}_{2} \mathrm{O}+\mathrm{K}_{2} \mathrm{O}\right.$ moles $) / \mathrm{SiO}_{2}$ after Chappell and White (1974). c. Classification of granitoids after Streckeisen (1976). 1. Western Carpathian plutons, 2. Central Bohemian plutons, eastern part of southern Bohemian plutons, Tisia Terrane, 3. Pelso Terrane, Southern Alps, western part of southern Bohemia plutons (Buda et al. 2004) 


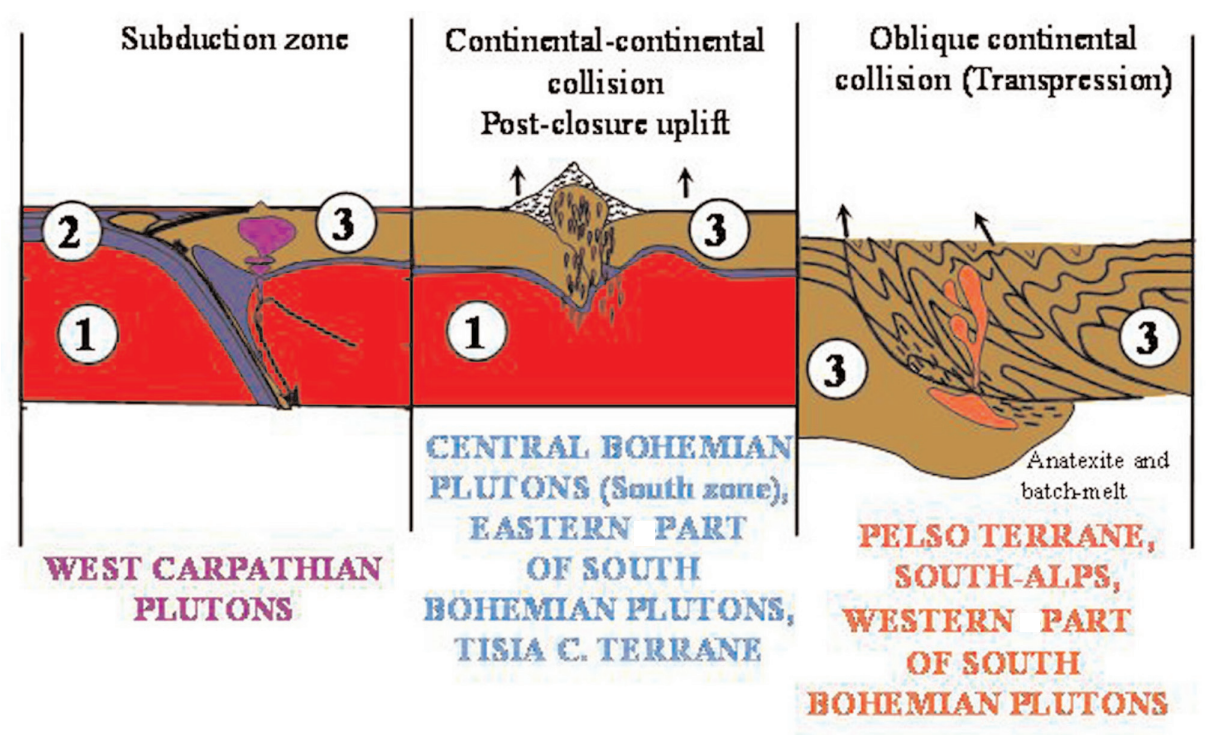

Fig. 6

Plate tectonic position of Central European Variscan granitoids. 1. Upper mantle, 2. Oceanic crust, 3. Continental crust

In the junction area of the Slavonia-Dravia and Kunság Units (region of the Mecsek and Villány Mts) a fault-controlled basin was formed after the Variscan Orogeny, in which up to 3,500 m of Upper Carboniferous to Upper Permian molasse sediments accumulated, with significant rhyolitic volcanism in the Early Permian. Other parts of the Tisia Composite Terrane in the territory of Hungary were subject to denudation during Late Variscan times (Kovács et al. 2000).

The Alpine overstep sequence in the northern zones of the Tisia Terrane began with Lower Triassic Buntsandstein-type continental redbeds, although shallowmarine sedimentation in the southernmost zones had already begun at this time (Bleahu et al. 1994). However, the predominant part of the area of the Tisia Terrane was only affected by marine inundation during the Middle Triassic ("Muschelkalk Stage"; Török 1993, 2000; Feist-Burkhardt et al 2008) from the S (Bleahu et al. 1994). Following retreat of the sea at the beginning of the Late Triassic the Mecsek Zone began to separate from the southerly-lying areas: the former became a zone of rapidly sinking half-grabens, whereas the latter remained relatively elevated, typified by shallow-marine threshold facies (see Kovács et al. 2006, for latest review). Thereafter, in the Mecsek Zone, the halfgrabens were filled with up to $4,500 \mathrm{~m}$ of siliciclastics, followed by mixed marlysiliciclastic sediments (Upper Triassic atypical grey "Keuper", a Lower Liassic Gresten-type sequence with thick coal measures, and finally Middle Liassic to Bajocian spotty marl or "Fleckenmergel"). The siliciclastic detritus was derived from a northerly lying granitoid-metamorphic provenance (Nagy 1968, 1971; Haas et al. 2001; Haas and Péró 2004). However, in the presently adjacent 
Zagorje-Mid-Transdanubian-Bükk Zone marine conditions prevailed since the Middle-Late Permian (Bérczi-Makk et al. 1993; Haas et al. 2000; Filipovic et al. 2003), thus excluding that it could have been the source area of siliciclastics filling up the half-graben(s). Contemporaneously, the Villány-Bihor Ridge was an area of episodic deposition of Late Triassic, continental - peritidal, Carpathian Keupertype sediments or Liassic shallow-marine sediments of reduced thickness that overlay the Middle Triassic carbonates (Vörös 2009). Accordingly it also could not have been an alternative provenance of the siliciclastic sequence of the Mecsek Zone.

From the Bathonian onward the Mecsek Zone displayed a typical rifted margin evolution until the earliest Cretaceous, with deep-water carbonate and siliceous sedimentation, but without any significant siliciclastic input (Haas and Péró 2004), and changing its faunal character from boreal to mediterranean (Vörös 1993). Alkaline rift-type basalt volcanism occurred sporadically during the Late Jurassic, but its paroxysm occurred in the Valanginian (Harangi 1994). Petrologic and geochemical data point to close correlation with contemporaneous volcanism of the Beskide Mts of the Polish Carpathians (Harangi et al. 2003). Paleomagnetic data bear evidence of coordinated movements of the Mecsek area with Europe from the Carboniferous to the earliest Cretaceous; thereafter a major anti-clockwise rotation took place during the paroxysm of volcanism at $135 \mathrm{Ma}$ (Márton 2000) or somewhat later at about 120 Ma (Harangi and Árva-Sós 1993).

In the Villány Zone shallow marine Late Jurassic and Urgon-type Early Cretaceous carbonate sedimentation was followed by flysch-type siliciclastic sedimentation in the Albian to Cenomanian (Császár 2002). The first stage of north-vergent thrusting was likely coeval with the latter. In the Senonian flysch complexes were deposited in the eastern part of both the Mecsek and Villány Zones, in flexural basins formed in front of the advancing nappe piles. In the former zone flysch sedimentation continued in the Paleogene (Szolnok Flysch Zone, which is considered to be the continuation of the Inner Carpathian Maramures flysch) on the northern continental slope of the Tisia Terrane, very probably in a "foreland basin" setting (Nagymarosy and Báldi-Beke 1993).

\section{Southern zones of the ALCAPA Composite Terrane}

Between the Mid-Hungarian Line and the Periadriatic-Balaton Line, in the highly-sheared Mid-Hungarian Zone (or Zagorje-Mid-Transdanubian-Bükk Zone; Pamic et al. 2002, 2004; Pamic 2003), elements of the eastern Southern Alps and of the Inner Dinarides occur (Haas et al. 2000; Haas and Kovács 2001; Kovács and Haas 2010).

NNW of the Periadriatic-Balaton Line, the Bakonyia Terrane (Transdanubian Range Unit) is made up of very low to low-grade metamorphic Variscan formations that are overlain by non-metamorphosed Late Paleozoic, Mesozoic and Paleogene series showing mostly South Alpine affinity. In the southernmost 
part of the Bakonyia Terrane, along the Periadriatic-Balaton Line, post-orogenic, small, hypabyssal granite intrusions occur (Buda et al. 2004) containing smaller peraluminous/peralkaline, S/A-type intrusions of Permian age (280-275 Ma), probably indicating initial rifting (Uher and Broska 1996; Buda et al. 2010).

No Variscan metamorphism has been proved in the Mid-Hungarian Zone. In the Bükk and the South Karavank Units marine sedimentation prevailed throughout the Late Paleozoic, continuing into the Triassic. In the Bükk there is a hiatus in the Early Permian; however, coeval marine sediments have been identified in the Hungarian extension of the South Karavanka Unit (Bérczi-Makk and Kochansky-Devidé 1981). The Alpine/Neotethyan sedimentary cycle began in the Middle Permian with evaporites-siliciclastics (Pelikán 2005). From the Late Permian to the end of the Triassic shallow marine, mostly carbonate sedimentation took place, interrupted in the Early Ladinian by a significant calcalkaline (mostly andesitic) volcanic event (Harangi et al. 1996). Differentiation of platform and basin environments occurred in the Late Triassic in the Bükk Unit. Upper Jurassic distal flysch-type sediments of the "Eohellenic phase" terminate the Alpine sedimentary cycle (Haas et al. 2001). In the ophiolite mélange remnants (Kalnik, Darnó and Szarvaskó Units) Triassic (LadinianCarnian) and Jurassic (mostly Bathonian-Callovian) MOR-type basalt is proved by associated radiolarian chert and by radiometric data (Ârva-Sós et al. 1987; Dosztály and Józsa 1992; Dosztály et al. 1998; Pamic and Tomljenovic 1998; Halamic et al. 1999; Gorican et al. 2005). Middle-Upper Jurassic olistostromes with fine siliciclastic matrix and turbidites (either siliciclastic or carbonate) were related to the Neotethyan oceanic closure ("Eohellenic tectogenesis").

\section{Relationships}

Detailed geochemical, petrologic and geochronological correlative studies revealed that the granitoid range of the Mecsek Zone (Mórágy Complex, TCT) could be the eastern continuation of the Variscan Moldanubian Zone and could have been located in the vicinity of the southeastern part of the Bohemian Massif. Variscan metamorphic and granitoid rocks of the more southern zones of Tisia could represent a continuation of the Mediterranean Crystalline Zone of the Alps-(Central) West Carpathians [in the sense of Neubauer and von Raumer (1993)] containing mostly I-type subduction-related granitoids in the West Carpathians (Figs 3-6) and I/S-type (Horvat and Buda 2004) in the Psunj and Papuk Mts (Croatia). During the Triassic the Mecsek Zone belonged to the Peritethyan Zone and could have been located similarly close to the southeastern corner of the Bohemian Massif (Török 2000; Kovács et al. 2010; Fig. 7). Paleomagnetic data indicate an anomalously high $\left(45^{\circ} \mathrm{N}\right)$ paleolatitude in the Anisian (Márton 2000). According to sedimentary and paleontological records, it began to be dismembered from the European plate in the Bathonian (due to Penninic rifting). However, paleomagnetic data show a major anticlockwise 
rotation only in the Berriasian, during the early stage of the alkaline rift-type volcanism (Márton 2000). These volcanics show correlation with coeval ones of the Beskides of the Polish Carpathians (Harangi et al. 2003; Figs 8-10).

In contrast (Fig. 11) to the northern zones of Tisia, Variscan and Late Variscan evolution of the elements of the Mid-Hungarian (Zagorje-Mid-TransdanubianBükk) Zone suggests that they belonged to the southernmost Variscan Zone, i.e. to the Noric-Bosnian Zone [in the sense of Neubauer and von Raumer (1993)], or to the Carnic-Dinaridic "microplate" [in the sense of Vai $(1994,1998)]$. The Late

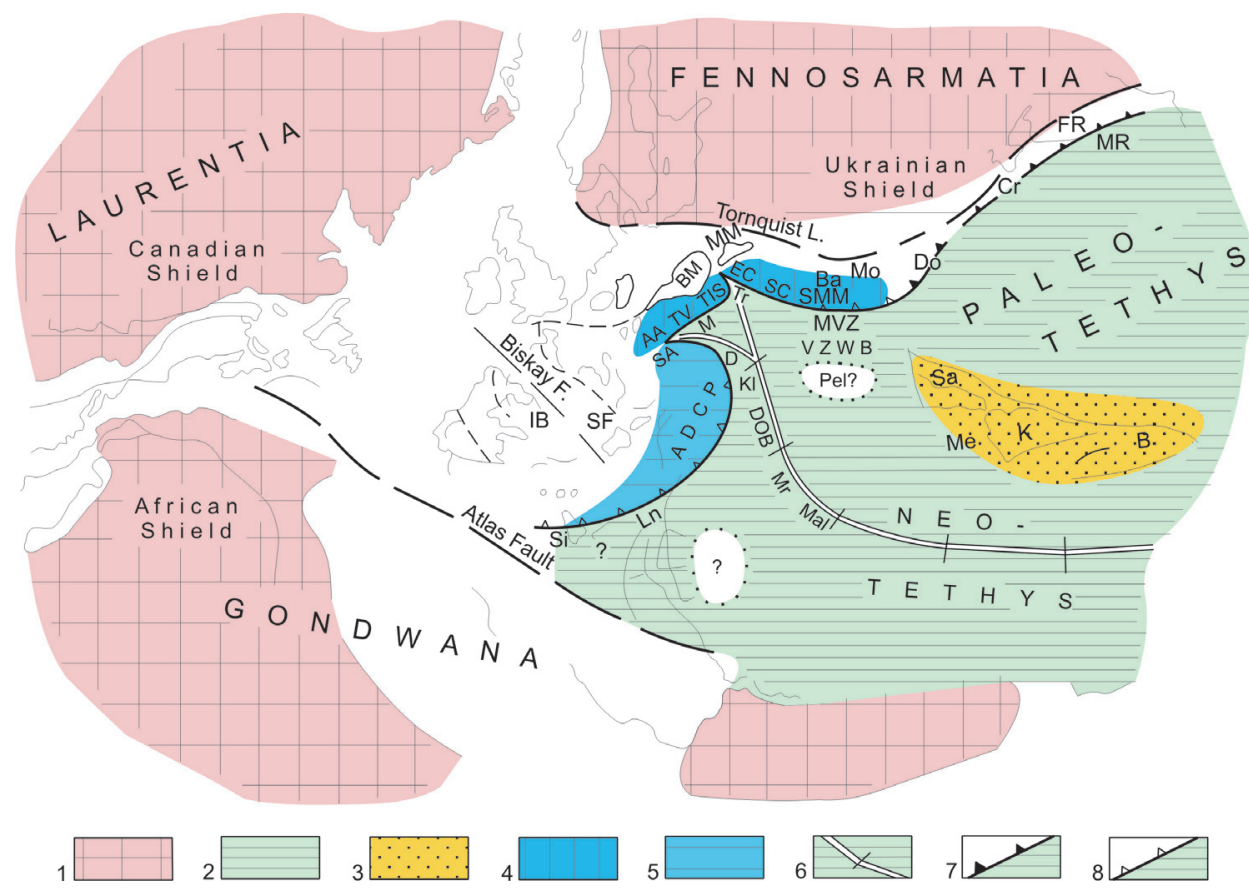

Fig. 7

Late Triassic (Norian) paleogeographic reconstruction of the northwestern end of Neotethys (Flügel's map (1990) was applied for the Pangaean frame). Legend and abbreviations: 1. Precambrian shields; 2. Tethyan oceanic domains; D - Darnó Unit, DOB - Dinaridic Ophiolite Belt, K - Kalnik Unit, L Lagonegro Basin, M - Meliata Unit, Mal - Maliak Zone, Mr - Mirdita Zone, MVZ - Main Vardar Zone, $\mathrm{Si}$ - Sicani Basin, Tr - Transylvanides, VZWB - Vardar Zone Western Belt; 3. Cimmerian continental blocks: B - Bitlis, K - Kirsehir, Me - Menderes, Sa - Sakarya; Pel? - "Pelagonia" (only Flambouron Nappe); 4. European margin: AA - Austroalpine domain, Ba - Balkanides, EC - Eastern Carpathians, M - Moesia, SC - Southern Carpathians, SMM - Serbo-Macedonian "Massif", TIS - Tisia, TV - TatroVeporicum (Central West Carpathians); 5. Adriatic margin: ADCP - Adriatic-Dinaridic Carbonate Platform, SA - Southern Alps; 6. Spreading axis; 7. Active Paleotethyan subduction zone: Do - North Dobrogea, Cr - South Crimea, FR - Fore Range of Caucasus, MR - Main Range of Caucasus; 8. Inactive (pre-Late Carnian) Paleotethyan subduction zone. Emerged Variscan areas in the European foreland: BM - Bohemian Massif, MM - Malopolska Massif. For an alternative model of opening of DOB (Dinaridic Ophiolite Belt) (by southwestward subduction in the Main Vardar Zone) see Karamata (2006) 


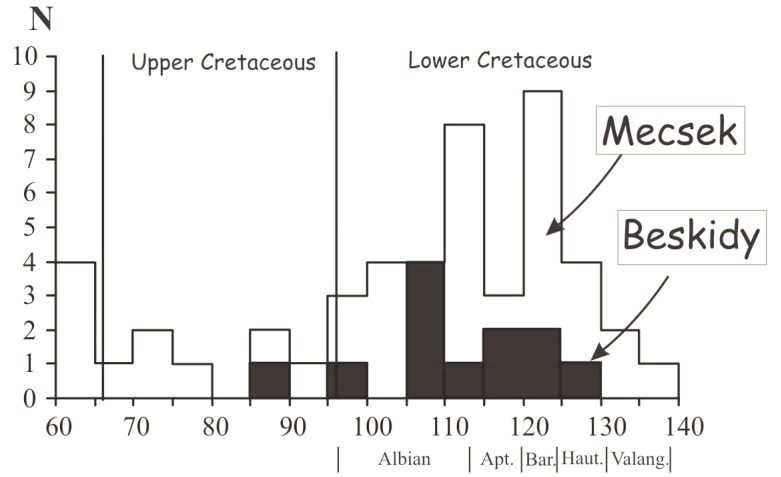

K/Ar age [Ma]
Fig. 8

Distribution of the $\mathrm{K} / \mathrm{Ar}$ age data for the igneous rocks of the Mecsek Mts and the SilesianMoravian Beskidy area. Data are from Harangi and Árva-Sós (1993) and Harangi et al. (2003)

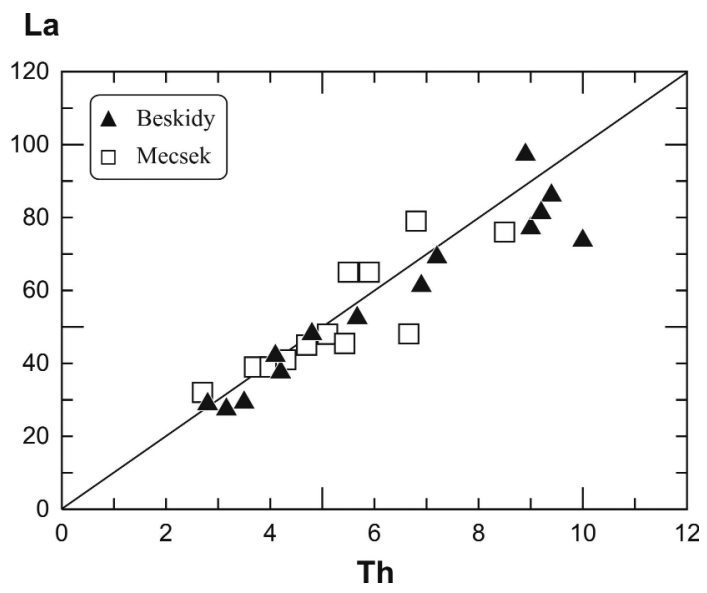

Fig. 9

La vs. Th diagram for the Early Cretaceous igneous rocks of the Mecsek Mts and the SilesianMoravian Beskidy area: the linear correlation and zero intercept indicate cogenetic relationship and derivation of the magmas from the same mantle source region

Fig. 10

The La-Nb covariation suggests a magma source region similar to the St. Helena-type HIMU OIB source

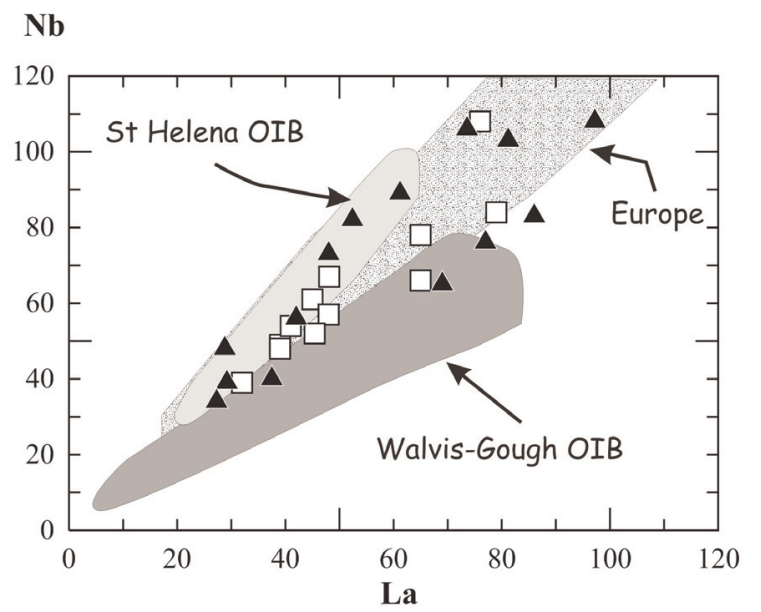




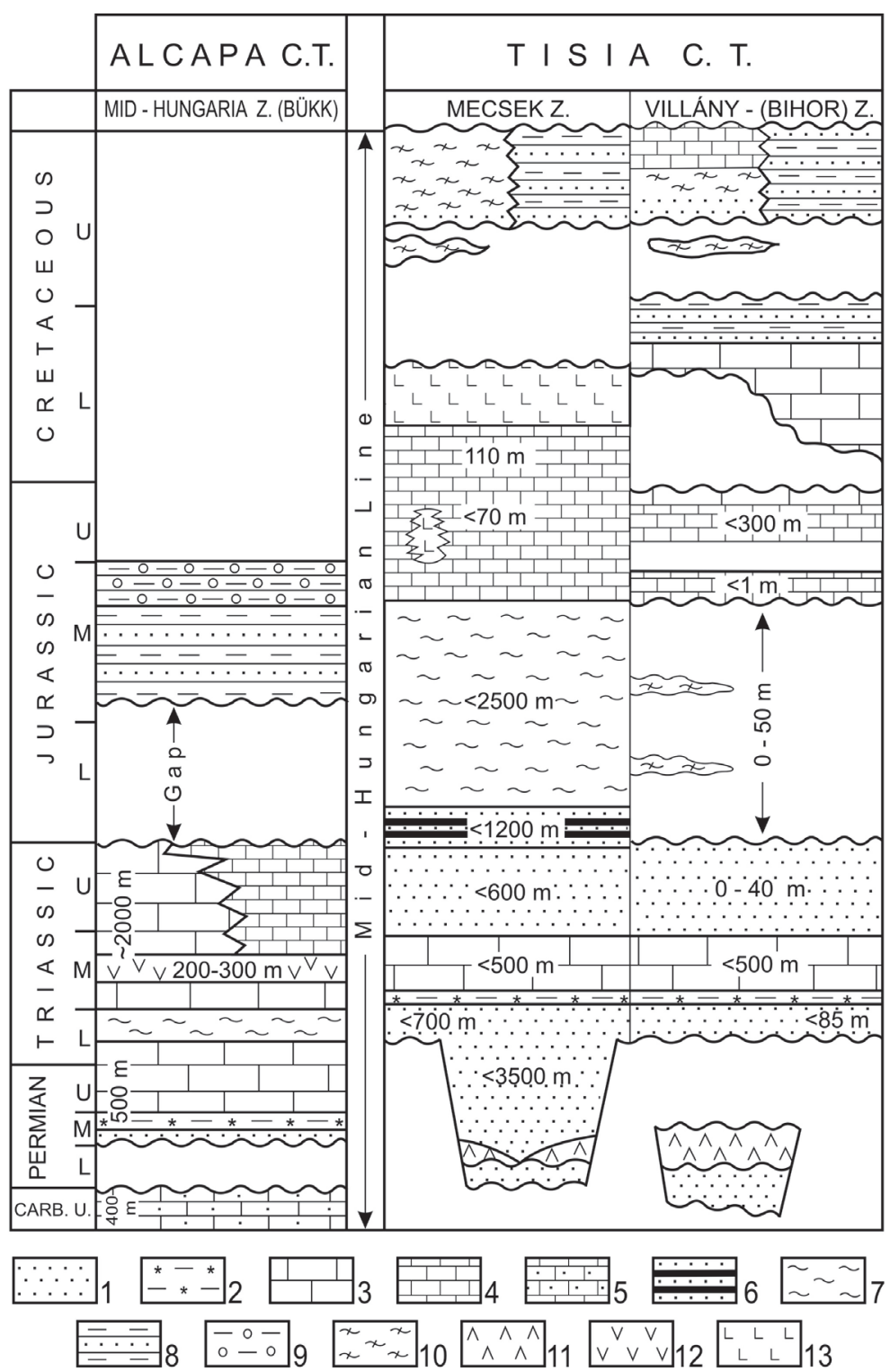

Fig. 11

Stratigraphic columns showing the contrasting Late Variscan-Alpine sedimentary and magmatic evolution of the units presently juxtaposed along the Mid-Hungarian Lineament. 1. Continental clastics; 2. evaporites; 3. shallow-marine carbonates; 4 . basinal/pelagic carbonates; 5 . late Variscan marine molasse; 6. paralic coal-bearing siliciclastic sequence (Gresten Facies in the Liassic); 7. marine, mixed siliciclastic-carbonate deposits ("Fleckenmergel" or Allgäu Facies in the Jurassic); 8. flysch; deepsea siliciclasts; olistostromes; 9. pelagic marl; 10. Lower Permian rhyolite; 11. Middle Triassic volcanics (mostly andesite); 12. Lower Cretaceous alkaline rift-type basaltic rocks 
Paleozoic and Triassic evolution of the Bükk Terrane of NE Hungary, the Jadar Terrane of W Serbia and Sana-Una Terrane of NW Bosnia show especially close relationships and indicate their original proximal or adjacent position (Protic et al. 2000; Filipovic et al. 2003). The same is valid for the Jurassic ophiolite mélange and turbidite complexes (Darnó, Szarvaskő, Mónosbél), which represent a displaced continuation of the Dinaridic Ophiolite Belt (Dimitrijevic et al. 2003; Haas et al. 2006).

\section{Conclusions}

1. The presently adjacent southernmost zone of the ALCAPA Composite Terrane (Mid-Hungarian Zone) and the northernmost zones of the Tisia Terrane (Mecsek and Villány Zones) show entirely different Variscan and Alpine evolution and relationships. This sharp difference in the Devonian to Jurassic evolution of the two presently adjacent terranes/zones is primarily reflected by the following events: a) intense Variscan granitization and amphibolite facies metamorphism in the pre-Alpine basement of the Mecsek Zone versus no evidence for Variscan metamorphism in the Mid-Hungarian Zone; b) Late Variscan continental molasse deposition in the Mecsek Zone versus shallow marine sedimentation; c) onset of Neotethyan transgression with the sabkha stage only at the beginning of Middle Triassic in the Mecsek Zone, but already in the Middle Permian in the Mid-Hungarian Zone; d) no Triassic volcanism in the Mecsek Zone versus intense Ladinian-Carnian volcanism; e) up to several kmthick siliciclastic deposition in the Mecsek half-graben zone (Late Triassic-early Middle Jurassic), derived from a northerly lying granitoid-metamorphic provenance, where presently the Mid-Hungarian Zone is found, with marine sedimentation already from the Middle Permian onward; f) Neotethyan accretionary complexes in the Mid-Hungarian Zone (displaced from its original site, in the Dinarides) in the Middle-Late Jurassic, versus typical rifted margin evolution (related to the Penninic Ocean opening) in the Mecsek Zone from the late Middle Jurassic onward, with paroxysm of alkaline rift-type basalt volcanism in the Early Cretaceous.

2. The two composite terranes only became juxtaposed by means of a major dextral transpressional regime that can be kinematically considered as the MidHungarian Zone (cf. Csontos and Nagymarosy 1998) at the end of the Early Miocene (Karpathian), through large-scale opposite rotations and strike-slip

displacement of the two mega-units. The first true overstepping deposits are of Badenian age, already showing the docking of the two major terranes along the Mid-Hungarian Line.

3. In this shear zone, Inner Dinaridic and eastern South Alpine elements of the Zagorje-Mid-Transdanubian-Bükk Zone are squeezed out along the MidHungarian Line, which is the NW border of the Tisia Terrane per definitionem. 
4. The northern margin of the Tisia Terrane (e.g. the Mecsek Zone) showed a typical rifted margin evolution during the Late Jurassic - Early Cretaceous. This fact contradicts models published some 10 years ago, in which the MidHungarian Line appears during this time interval as a suture zone, or the Mecsek Zone as an active margin (Golonka et al. 2000; Plašienka et al. 1997).

\section{Acknowledgements}

The preparation of this paper was funded by the National Research Fund, grants No. T-037595 and T-047121, T-037966, K-61872, K-67787, T-037510, T-029655 and by the Ministry of Education Research Fund FKFP 0181/1999.

\section{References}

Árva-Sós, E., K. Balogh, L. Ravasz-Baranyai, Cs. Ravasz 1987: K/Ar dates of Mesozoic igneous rocks in some areas of Hungary. - MÁFI Évi Jel., 1985, pp. 295-307. Budapest (In Hungarian with English summary.)

Bérczi-Makk, A., V. Kochansky-Devidé 1981: Marin Lower and Middle Permian in the oil exploratory well Újfalu-1 (SW Hungary). - Acta Geol. Hung., 24, pp. 117-128.

Bérczi-Makk, A., J. Haas, E. Rálisch-Felgenhauer, A. Oravecz-Scheffer 1993: Upper Paleozoic-Mesozoic formations of the Mid-Transdanubian Unit and their relationships. - Acta Geol. Hung., 36, pp. 263-296.

Bleahu, M., G. Mantea, S. Bordea, S. Panin, M. Stefanescu, K. Sikic, J. Haas, S. Kovács, Cs. Péró, A. Bérczi-Makk, Gy. Konrád, E. Nagy, E. Rálisch-Felgenhauer, Á. Török 1994: Triassic facies types, evolution and paleogeographic relations of the Tisza Mega-unit. - Acta Geol. Hung., 37/3-4, pp. 187-234.

Buda, Gy. 1996: Correlation of Variscan granitoids occurring in Central Europe. - Acta Miner. -Petr. Szeged, 37, Suppl., p. 24.

Buda, Gy., F. Koller, J. Ulrych 2004: Petrochemistry of Variscan granitoids of Central Europe: Correlation of Variscan granitoids of Tisia and Pelsonian Terranes with granitoids of Moldanubicum, Western Carpathian and Southern Alps. A review: part I. - Acta. Geol. Hung., 47, pp. 117-138.

Buda, Gy., G. Dobosi 2004: Lamprophyre-derived high-K mafic enclaves in Variscan granitoids from the Mecsek Mts. (South Hungary). - N. Jb. Miner. Abh., 180/2, pp. 115-147.

Buda, Gy., G. Nagy, E. Pál-Molnár, F. Koller 2009: Two main types of Variscan granitoids in the Tisia Composite Terrane (Hungary). - Mitteilungen der Österreichischen Mineralogischen Gesellschaft, 155, 39.

Buda, Gy., F. Koller, E. András, G. Nagy 2010: Hungarian Variscan granitoids and their correlation with surrounding granitoids. - In: Zaharia, L., A. Kis, B. Topa, G. Papp, T.G. Weiszburg (Eds): IMA2010 20th General Meeting of the International Mineralogical Association. - Acta Miner. Petr., Abstract Series, 6, p. 507.

Chappell, B.W., A.J.R. White 1974: Two contrasting granite types. - Pacific Geol., 8, pp. 173-174.

Streckeisen, A. 1976: To each plutonic rock its proper name. - Earth Science Reviews. International Magazine for Geo-Scientists. Amsterdam. Vol. 12, pp. 1-33.

Csontos, L., A. Nagymarosy 1998: The Mid-Hungarian line: a zone of repeated tectonic inversions. Tectonophysics, 297, pp. 51-71.

Dimitrievic, M.D. 1992: Geological Atlas of Serbia. 1:2000 000 I. - Geological Map. Grafimex. Belgrade. 
Dimitrijevic, M.N., M.D. Dimitrijevic, S. Karamata, M. Sudar, N. Gerzina, S. Kovács, L. Dosztály, Z. Gulácsi, Gy. Less, P. Pelikán 2003: Olistrotrome/mélanges - an overview of the problems and preliminary comparison of such formations in Yugoslavia and NE Hungary. - Slovak Geological Magazine, 9, pp. 3-21.

Dosztály, L., Z. Gulácsi, S. Kovács, 1998: Az észak-magyarországi jura képződmények rétegtana (Stratigraphy of North Hungarian Jurassic formations). - In: Bérczi, I., Á. Jámbor (Eds): Magyarország geológiai képződményeinek rétegtana (Stratigraphy of geological formations of Hungary), pp. 309-318, MOL Rt. and MÁFI, Budapest.

Dosztály, L., S. Józsa 1992: Geochronological evaluation of Mesozoic formations of Darnó Hill at Recsk on the basis of radiolarians and K-Ar age data. - Acta Geol. Hung., 35/4, pp. 371-393.

Ellenberger, F., A.L.G. Tamain 1980: Hercynian Europe. - Episodes, 1/1, pp. $22-25$.

Feist-Bruckhardt, S., A. Götz, J. Szulc, R. Borkhataria, M. Geluk, J. Haas, J. Hornung, P. Jordan, O. Kempf, J. Michalik, J. Nawrocki, L. Reinhardt, W. Ricken, H., Röhling, T. Rüffer, Á. Török, R. Zühlke 2008: Triassic. - In: McCann, T. (Ed.): The geology of Central Europe, V2: Mesozoic and Cenozoic, Geological Society, London, pp. 750-821.

Filipovic, I., D. Jovanovic, M. Sudar, P. Pelikán, S. Kovács, Gy. Less, K. Hips 2003: Comparison of the Variscan - Early Alpine evolution of the Jadar Block (NW Serbia) and "Bükkium" (NE Hungary) terranes; some paleogeographic implications. - Slovak Geol. Mag., 9/1, pp. 3-21.

Fülöp, J., K. Brezsnyánszky, J. Haas 1987: The new map of basin basement of Hungary. - Acta Geol. Hung., 30/1-2, pp. 3-20, Budapest.

Golonka, J., N. Oszcypko, A. Slaczka 2000: Late Carboniferous - Neogene geodynamic evolution and paleogeography of the Circum-Carpathian region and adjacent areas. - Annales Societas Geologorum Poloniae, 70, pp. 107-136.

Gorican, S., J. Halamic, T. Grgasovic, T. Kolar-Jurkovšek 2005: Stratigraphic evolution of Triassic arcbackarc system in northwestern Croatia. - Bulletin Societé Géolologique de la France, 176/1, pp. $3-22$.

Haas, J., Á. Görög, S. Kovács, P. Ozsvárt, I. Matyók, P. Pelikán. 2006: Displaced Jurassic foreslope and basin deposits of Dinaridic origin in Northeast Hungary. - Acta Geol. Hung., 49/2, pp. 125-163.

Haas, J., G. Hámor, Á. Jámbor, S. Kovács, A. Nagymarosy, T. Szederkényi 2001: Geology of Hungary - Eötvös University Press, Budapest, 317 p.

Haas, J., S. Kovács 2001: The Dinaridic-Alpine connection as seen from Hungary. - Acta Geol. Hung., 44/2-3, pp. 345-362.

Haas, J., P.J. Mioc, J. Pamic, B. Tomljenovic, P. Árkai, A. Bérczi-Makk, B. Koroknai, S. Kovács, E. Rálisch-Felgenhauer 2000: Complex structural pattern of the Alpine-Dinaridic-Pannonian triple junction. - Int. Journ. Earth Sciences, 89/2, pp. 377-389.

Haas, J., Cs. Péró 2004: Mesozoic evolution of the Tisza Megaunit. - International Journal of Earth Sciences, 93, pp. 297-313.

Halamic, J., Š. Gorican, D. Slovenec, T. Kolar-Jurkovšek 1999: A Middle Jurassic radiolarite-clastic succession from the Medvednica Mt. (NW Croatia). - Geologica Croatica, 52/1, pp. 29-57.

Harangi, Sz. 1994: Geochemistry and petrogenesis of the Early Cretaceous continental rift-type volcanic rocks of the Mecsek Mountains, South Hungary. - Lithos, 33, pp. 303-321.

Harangi, Sz., E. Árváné-Sós 1993: A Mecsek hegység alsókréta vulkáni kőzetei. I. Ásvány- és kőzettan. [Early Cretaceous volcanic rocks of the Mecsek Mountains (South Hungary) I. Mineralogy and petrology] - Földtani Közlöny, 123/2, pp. 129-165.

Harangi, Sz., Cs. Szabó, S. Józsa, Zs. Szoldán, E. Árva-Sós, M. Balla, I. Kubovics, I. 1996: Mesozoic Igneous Suites in Hungary: Implications for Genesis and Tectonic Setting in the Northwestern Part of Tethys. - Int. Geol. Rev., 38, pp. 336-360.

Harangi, Sz., S. Tonarini, O. Vaselli, P. Manetti 2003: Comparison of geochemistry and petrogenesis of Lower Cretaceous alkaline volcanic rocks of the Mecsek Mts. and the Moravian-Silesian Beskidy. - Acta Geol. Hung., 46/1, pp. 77-94.

Horvat, M., Gy. Buda 2004: Geochemistry and petrology of some granitoids from Papuk and Psunj Slavonian Mountains (Croatia). - Acta Min. Petr. Szeged, 45, pp. 93-100. 
Karamata, S. 2006: The geological development of the Balkan Peninsula related to the approach, collision and compression of Gondwanan and Eurasian units. - In: Robertson, A.H.F., D. Mountrakis (Eds): Tectonic Development of the Eastern Mediterranean Region, Geol Soc., London, Spec. Publ., 260, pp. 155-178.

Klötzli, U.S., Gy. Buda, F. Koller. 1999: Geochronological evidence for the derivation of the Mecsek Mountains, South Hungary, from Variscan Central Europe. - Beih. z. Eur. J. Mineral., 11/2, p. 126.

Klötzli, U.S., Gy. Buda, T. Skiöld 2004: Zircon typology, geochronology and whole rock Sr-Nd isotope systematics of the Mecsek Mountain granitoids in the Tisia Terrane (Hungary). - Min. and Petr., 81, pp. 113-134.

Kovács, S., J. Bóna, E. Rálisch-Felgenhauer. 2005: Middle Anisian (Pelsonian) platform conodonts from the Triassic of the Villany Hills, South Hungary. - Acta Geol. Hung., 48/1, pp. 107-115.

Kovács, S., K. Brezsnyánszky, J. Haas, T. Szederkényi, F. Ebner, J. Pamic, B. Tomljenovic, M. Gaetani, G.-B. Vai, H.G. Kräutner, S. Karamata, B. Kristic, J. Vozár, A. Vozárová, P. Mioc (Eds): 2004: Tectonostratigraphic terrane and paleoenvironment maps of the Circum-Pannonian region. 1:2 500 000. - Hung. Geol. Inst., Budapest.

Kovács, S., T. Szederkényi, J. Haas, Gy. Buda, G. Császár, A. Nagymarosy 2000: Tectonostratigraphic terranes in the pre-Neogene basement of the Hungarian part of the Pannonian area. - Acta Geol. Hung., 43/3, pp. 225-328.

Kovács, S., M. Sudar, S. Karamata, J. Haas, Cs. Péró, E. Gradinaru, H.-J. Gawlick, M. Gaetani, J. Mello, M. Polák, D. Aljinicic, B. Ogorelec, T. Kollar-Jurkovsek, B. Jurkovsek, S. Buser 2010: Triassic environments in the Circum-Pannonian region related to the initial Neotethyan rifting stage. - In: Vozár, J., F. Ebner, A. Vozarová, J. Haas, S. Kovács, M. Sudar, M. Bielik (Eds): Variscan and Alpine terranes of the Circum-Pannonian region. - Slovak Academy of Sciences, Geological Institute, Bratislava.

Kovács, S., J. Haas 2010: Displaced South Alpine and Dinaridic elements in the Mid-Hungarian Zone, Central European Geology. - (in this volume)

Lelkes-Felvári, Gy., P. Árkai, F.P. Sassi 1996: Main features of the regional metamorphic events in Hungary: A review. - Geol. Carpath., 47/4, pp. 257-270.

Nagy, E. 1968: Triasbildungen des Mecsek Gebirges. - Ann. Inst. Geol. Publ. Hung., 51, pp. 1-239.

Nagy, E. 1971: Der unterliassische Schichtenkomplex von Grestener Fazies im Mecsek Gebirge (Ungarn). - Ann. Inst. Geol. Hung., 54/2, pp. 155-159.

Márton, E. 2000: The Tisza Megatectonic Unit in the light of paleomagnetic data. - Acta Geol. Hung., 43/3, pp. 329-343.

Nagymarosy, A., M. Báldi-Beke 1993: The Szolnok Unit and its probable paleogeographic position. Tectonophysics, 226, pp. 457-470.

Neubauer, F., J.F von Raumer 1993: The Alpine Basement - Linkage between Variscides and EastMediterranean Mountain Belts. - In: von Raumer, J.F, F. Neubauer (Eds): Pre-Mesozoic Geology in the Alps, Springer-Verlag, pp. 641-664.

Pamic, J., B. Tomljenovic 1998: Basic geologic data from the Croatian part of the Zagorje-MidTransdanubian Zone. - Acta Geol. Hung., 41/4, pp. 389-400.

Pamic, J. 2003: The allochthonous fragments of the Internal Dinaridic units in the western part of the Pannonian Basin. - Acta Geol. Hung., 46/1, pp. 41-62.

Pamic, J., S. Kovács, J. Vozár 2002: The Internal Dinaridic fragments into the collage of the South Pannonian Basin. - Proceedings of the XVIIth Congress of Carpatho-Balkan Geol. Assoc., Geol. Carpath., 53, Spec. Issue, pp. 9-11.

Pamic, J., S. Kovács, A. Vozárova 2004: The role of Dinarides in the evolution of the Pannonian-Carpathian-Dinarides domain. - Manuscript, MÁFI Archive No. 21278, 36 p.

Pelikán, P. In: Pelikán, P. (Ed.) 2005: A Bükk hegység földtana (Geology of Bükk Mountains). Magyarázó a Bükk-hegység földtani térképéhez 1:50 000 (Explanatory Book to the Geological Map of the Bükk Mountains 1:50 000). - 284 p, MÁFI, Budapest. 
Protic, L., I. Filipovic, P. Pelikán, D. Jovanovic, S. Kovács, M. Sudar, K. Hips, Gy. Less, R. Cvijic 2000: Correlation of the Carboniferous, Permian and Triassic sequences of the Jadar Block, Sana-Una and "Bükkium" terranes. - In: Karamata, S., S. Jankovic (Eds): Proceedings of the International Symposium "Geology and Metallogeny of the Dinarides and the Vardar Zone", Banja Luka, pp. 61-69.

Plašienka, D., M. Putiš, M. Kovác, J. Šefara, I. Hrussecky 1997: Zones of Alpidic subduction and crustal underthrusting in the Western Carpathians. - In: Grecula et al. (Eds): Geological evolution of the Western Carpathians, Mineralia Slovaca Monograph, Bratislava, pp. 35-42.

Shatagin, K., I. Chernyshev, Z. Balla 2005: Geochronology of Mórágy Granite: Results of U-Pb, Rb-Sr, $\mathrm{K}-\mathrm{Ar}$ and 40Ar-39Ar isotope study (A Mórágyi Gránit geokronológiája: U-Pb, Rb-Sr, K-Ar és 40Ar-39Ar izotóp vizsgálatok eredményei. - MÁFI Évi Jel., 2004, pp. 41-64.

Streckeisen, A.L. 1976: To each plutonicrocks its propername. - Earth Sci. Rev., 12, pp. 1-33.

Szederkényi, T. 1996: Metamorphic formations and their correlation in the Hungarian part of the Tisza Mega-unit (Tisa Composite Terrane). - Acta Miner., Petr. Szeged, 37, pp. 143-160.

Török, Á. 1993: Storm influenced sedimentation in the Hungarian Muschelkalk. - In: Hagdorn, H., A. Seilacher (Eds): Muschelkalk, Ergebnisse des Schönthaler Symposium 1991, Stuttgart Sonderb. Gesellsch. Naturk. Würtenberg, 2, pp. 133-142.

Török, Á. 2000: Muschelkalk carbonates in southern Hungary: an overview and comparison to German Muschelkalk. - Zbl. Geol. Paläont., Teil I, 1998, 9-10, pp. 1085-1103.

Vai, G.B. 1994: Crustal evolution and basement elements in the Italian area: paleogeography and characterization. - Boll. Geofis. Teor. Appl., 36, pp. 411-434.

Vai G.B. 1998: Field trip through the Southern Alps: an introduction with geologic settings, paleogeography and Paleozoic stratigraphy. - Giorn. Geol., ser 3a, 60, Spec. Issue, ECOS VII Southern Alps Field Trip Guidebook, pp. 1-38.

Vörös, A. 1993: Jurassic microplate movements and brachiopod migrations in the western part of the Tethys. - Palaeogeogr., Palaeoclimatol., Paleoecol., 100, pp. 125-145.

Vörös, A. 2009: Tectonically-controlled Late Triassic and Jurassic sedimentary cycles on a periTethyan ridge (Villány, southern Hungary). - Central European Geology, 52, pp. 125-151.

Uher, P., I. Broska 1996: Post-orogenic Permian granitic rocks in the Western Carpathian-Pannonian area: geochemistry, mineralogy and evolution. - Geol. Carpatica, 47/5, pp. 311-321. 